\title{
天空放射輝度分布及び周囲遮蔽物を考慮した壁面日射量計算法の開発
} 一第 1 報 CIE 標準一般天空 Gradation 関数, Indicatrix 関数の近似関数を用いた壁面日射量計算法一

\section{DEVELOPMENT OF CALCULATION METHOD OF SURFACE IRRADIANCE VALUE AFFECTED BY SHADING OBJECTS AND THE SKY RADIANCE DISTRIBUTION}

Part 1 Calculation method with the approximations of the CIE gradation/indicatrix functions

\section{細淵勇人*1, 吉田治典*2 \\ Hayato HOSOBUCHI and Harunori YOSHIDA}

\begin{abstract}
On the calculation of the values of heating/cooling loads based on more real state of a building in the city, influences of the sky radiance distribution and the surroundings around the building should be take into account. However they have not been considered to be important factors.

In this paper, with the CIE standard general sky and the approximations that have analytic solution, we intend to present a new calculation method of surface irradiance value of the building surrounded by the other buildings. In the development, the accuracy of calculation and the processing time are made much account.
\end{abstract}

Keywords : Sky Radiance Distribution, CIE Standard General Sky, Surface Irradiance, Analytical Solution 天空放射輝度分布, CIE 標準一般天空, 壁面日射量, 解析解

1. 序

現在，建物の熱負荷計算を行う際には，天空の放射輝度分布を一様 とした天空日射量を用いるのが一般的である。この天空放射輝度分 布を考慮するため, 天空日射を一様, 準直達, 地平線部といった各 成分に分けて，それぞれの割合をモデル化する斜面日射モデルも開 発されている(1).21.3). 4).これらの斜面日射モデルは，壁面の受ける日 射量をモデル化したものであり，天空放射輝度分布そのもののモデ ルのように, 天球上での分布の積分を必要とせず，熱負荷計算への 応用も容易である。しかし斜面日射モデルは，天空放射輝度分布モ デルのように, 天球上の任意点の放射輝度を予測するものではな い.このため周辺建物等の遮蔽物を考慮するなど，より現実の環境 を想定して熱負荷計算を試みる場合などでは，現実との誤差が大き くなると考えられる。

一方，天空放射輝度分布モデル㓯え(ザ5) 6) や，CIE 標準一般天空などの 天空輝度分布モデル㽗ジ7, 8) といった分布そのもののモデルを壁面日 射量計算に利用できれば，より現実に近い環境を想定しても，精度 よく熱負荷計算等の熱環境シミュレーションを行えると考える。し かしこれらのモデルを用いて壁面日射量を計算するには，天球上で の分布の積分が必要となる. これには数值積分を用いることが考 えられるが，周囲に他の建物などの遮蔽物が存在するような， より現実に近い環境を想定する場合には，この計算時間は膨 大となり年間熱負荷計算等の応用には適さない。このような熱 シミュレーションに数值積分を用いるには, 時々刻々変化する太陽 位置と, 遮蔽物との位置関係による積分区間の判定など煩雑なプロ
セスが必要となる

現在，天空放射輝度分布のモデルを用いて，天空放射輝度分布， 周囲建物等の遮蔽物を考慮した壁面日射量を計算する一般的な手法 を開発し，これをシミュレーションプログラムに導入する等の応用 研究は見られない，例えば，国際標準となりつつあるエネルギーシ ミュレーションソフトウェア EnergyPlus ${ }^{9)}$ でも，天空輝度分布につい ては 4 つ天空状態の組み合わせとしているものの, 天空放射輝度分 布については, 前述した斜面日射モデルの採用に止まっている.

筆者らは，天空放射輝度分布を考慮した，より現実に即した熱環 境予測を行うことを目的として, 2003 年に国際照明委員会 (Commission Internationale De L'eclairage(CIE)) に標準モデルとして採用さ れた天空輝度分布のモデルである CIE 標準一般天空について, その 放射輝度への流用可能性，未だ国際標準化されていない天空タイプ 注1) の推定法を検討し，天空放射輝度分布の建物空調熱負荷への影響 を明らかにしてきた ${ }^{10)}$ １1）１2．本報では，CIE 標準一般天空を用いて， 天空放射輝度分布，遮蔽物を考慮した，精度はもちろん，計算速度 の観点からも，より現実に近い環境の熱シミュレーションに応用可 能な，新たな壁面日射量計算法の開発を検討する. 図 1 にこれまで の研究の流れおよび，本報の位置づけを示す．

\section{2. 天空放射輝度分布を考慮した壁面日射量}

\subsection{CIE 標準一般天空を用いた壁面日射量}

CIE 標準一般天空の相対輝度分布は, Gradation 関数 $\varphi(Z)$, Indicatrix 関数 $f(\chi)$ を用いて以下で与えられる.

\footnotetext{
本論は建築学会大会学術諎演会(仙台. 2009 $)^{13}$ 及び日本建築学会近畿支部研究発表会(大阪, 2009) ${ }^{14} に$ にいて発表した内容を加筆修正したものである。 秋田県立大学システム科学技術学部建築環境システム学科 Assistant Prof., Dept. of Architecture and Environment Systems, Faculty of Systems Science 助教・博士(工学)

*2 岡山理科大学工学部建築学科 教授・工博 (京都大学 名誉教授) and Technology, Akita Prefectural University, Ph. D.

Prof., Dept. of Architecture, Faculty of Engineering, Okayama University of Science, Dr. Eng. (Prof. Emeritus, Kyoto University)
} 
$\frac{L_{a}}{L_{z}}=\frac{f(\chi) \varphi(Z)}{f\left(Z_{s}\right) \varphi(0)}$

$$
=\frac{\left\{1+c \cdot\left[\exp (d \chi)-\exp \left(d \frac{\pi}{2}\right)\right]+e \cdot \cos ^{2} \chi\right\} \times\left\{1+a \cdot \exp \left(\frac{b}{\cos Z}\right)\right\}}{\left\{1+c \cdot\left[\exp \left(d Z_{s}\right)-\exp \left(d \frac{\pi}{2}\right)\right]+e \cdot \cos ^{2} Z_{s}\right\} \times\{1+a \cdot \exp (b)\}}
$$

これを放射輝度に流用し, 分布を考慮した傾斜面天空日射量は, $Z$ (天空要素の高度),$\alpha$ (天空要素の方位) について, 検討面からの 天空の可視範囲を積分し, 以下で求められる. 遮蔽を考慮するには, 積分区間を遮蔽範囲に対応して変化させれば良い。

$I_{s h_{-} C I E}=L_{z} \times \frac{1}{f\left(Z_{s}\right) \varphi(0)} \times \int_{Z} \int_{\alpha} f(\chi) \varphi(Z) \cdot \cos Z_{i} \cdot \sin Z \cdot d Z d \alpha$

(2) 式より, 周囲建物等による遮蔽および, 天空放射輝度分布を考 慮した鉛直面, 水平面注 2 ) に入射寸る天空日射量を求めるには, 天頂 放射輝度 $L_{z}$ は通常測定されていないため, 以下に示す (3) 式のよう に「遮蔽の無い場合の C I E 標準一般天空の水平面放射照度総計 ( I horizontal_CIE_nonshaded $) 」 に$ 対寸る, 「遮蔽を考慮したCIE 標準一般 天空の鉛直面あるいは水平面放射照度合計値( $I_{\text {vertical_CIE }}$ あるいは $\left.I_{\text {horizontal_CIE }}\right) 」$ 」比に, 測定した水平面天空日射量 $E_{\text {ed }}$ を撕けて やればよい.

$I_{\text {vertical }}\left(\right.$ or $\left.I_{\text {horizontal }}\right)=E_{\text {ed }} \times \frac{I_{\text {vertical_CIE }}\left(\text { or } I_{\text {horizontal_CIE }}\right)}{I_{\text {horizontal_CIE_nonshaded }}}$

ここで,

$I_{\text {horizontal_CIE_nonshaded }}$

$$
=L z \times \frac{1}{f\left(Z_{s}\right) \varphi(0)} \times \int_{Z=0}^{Z=\frac{\pi}{2}} \int_{\alpha=0}^{\alpha=2 \pi} f(\chi) \varphi(Z) \cdot \cos Z \cdot \sin Z \cdot d Z d \alpha
$$

$I_{\text {vertical_CIE }}$

$=L z \times \frac{1}{f\left(Z_{s}\right) \varphi(0)} \times \int_{Z=z_{1}}^{Z=z_{2}} \int_{\alpha=a_{1}}^{\alpha=a_{2}} f(\chi) \varphi(Z) \cdot\left(\sin Z \cos \left(\alpha-\alpha_{r}\right)\right) \cdot \sin Z \cdot d Z d \alpha$

$I_{\text {horizontal_CIE }}$

$$
=L z \times \frac{1}{f\left(Z_{s}\right) \varphi(0)} \times \int_{Z=z_{1}}^{Z=z_{2}} \int_{\alpha=a_{1}}^{\alpha=a_{2}} f(\chi) \varphi(Z) \cdot \cos Z \cdot \sin Z \cdot d Z d \alpha
$$

鉛直面, 水平面の日射量は, 以下の (7), (8) 式を計算すればよい. $I_{\text {vertical }}$

$=E_{e d} \times$

$$
\frac{L z \frac{1}{f\left(Z_{s}\right) \varphi(0)} \int_{Z=z_{1}}^{Z=z_{2}} \int_{\alpha=a_{1}}^{\alpha=a_{2}} f(\chi) \varphi(Z)\left(\sin Z \cos \left(\alpha-\alpha_{r}\right)\right) \sin Z d Z d \alpha}{L z \frac{1}{f\left(Z_{s}\right) \varphi(0)} \int_{Z=0}^{Z=\frac{\pi}{2}} \int_{\alpha=0}^{\alpha=2 \pi} f(\chi) \varphi(Z) \cos Z \sin Z d Z d \alpha}
$$$$
=E_{e d} \times \frac{\int_{Z=z_{1}}^{Z=z_{2}} \int_{\alpha=a_{1}}^{\alpha=a_{2}} f(\chi) \varphi(Z)\left(\sin Z \cos \left(\alpha-\alpha_{r}\right)\right) \sin Z d Z d \alpha}{\int_{Z=0}^{Z=\frac{\pi}{2}} \int_{\alpha=0}^{\alpha=2 \pi} f(\chi) \varphi(Z) \cos Z \sin Z d Z d \alpha}
$$

I horizontal $\int_{Z=0}^{Z=\frac{\pi}{2}} \int_{\alpha=0}^{\alpha=2 \pi} f(\chi) \varphi(Z) \cos Z \sin Z d Z d \alpha$

$$
=E_{\text {ed }} \times \frac{\int_{Z=z_{1}}^{Z=z_{2}} \int_{\alpha=a_{1}}^{\alpha=a_{2}} f(\chi) \varphi(Z) \cdot \cos Z \cdot \sin Z \cdot d Z d \alpha}{\int_{Z=0}^{Z=\frac{\pi}{2}} \int_{\alpha=0}^{\alpha=2 \pi} f(\chi) \varphi(Z) \cdot \cos Z \cdot \sin Z \cdot d Z d \alpha}
$$

上記 (7), (8) 式の積分部分は, 数值積分により計算することが考 えられるが, 遮蔽物を考虑するような詳細な年間熱負荷計算等への 応用を考えた場合, 太陽位置が時刻ごとに変化し, 放射輝度分布も 変化するため, 毎時, 壁面方位別の数値積分が必要となり, 計算時 間が膨大となることが考えられる.
天空放射輝度分布を考慮した熱負荷計算

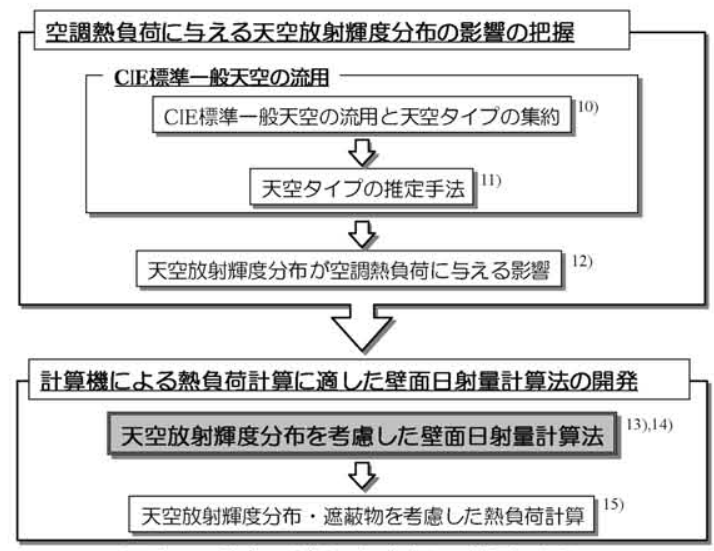

図 1 研究の流れと本報の位置づけ

\section{2 計算法開発の検討}

年間熱負荷計算等への応用を前提とする, 天空放射輝度分布およ び，周囲建物等による遮蔽を考慮した新たな壁面日射量計算法開発 の方針を見出すため, 計算時間の要する数值積分によらずに(7), (8) 式を計算する方法について検討した.

\section{(1)解析解を求める方法}

CIE 標準一般天空の Gradation 関数, Indicatrix 関数そのものの解析解 を求める.この方法は $\chi$ の関数となる Indicatrix 関数の $\chi$ に関する項に より解析解が求まらず, 不可能である. なお, これはCIE 標準一般 天空をはじめとする, 太陽との角距離 $\chi$ の関数で表す既往の分布モ デルすべて (5) 8),16) 20) について当てはまり，これら既往の分布モデル を利用する場合には, 新たな計算法の開発が必要となる.

\section{(2)解析解の求まる近似関数を用いる方法}

Gradation 関数, Indicatrix 関数それぞれを解析解の求まる簡易な式に 近似する.この方法は Indicatrix 関数が $Z_{s}, Z, \alpha, \alpha$ 変数になり簡 易な近似関数が作れない.

\section{(3)座標変換による方法}

Indicatrix 関数を $Z_{s}, Z, \alpha_{s}, \alpha$ で表す $\chi$ ではなく, 太陽位置 $Z_{s}, \alpha_{s}$ を原点として, $Z_{s}, \alpha_{s}$ からのずれ $Z^{\prime}, \alpha^{\prime}$ の関数として定義しなおす ことで, $\chi$ が含まれるのを回避する.この方法では, Indicatrix 関数の值 は太陽位置で顕著に大きく, 太陽位置で不連続になるため, 積分区 間を分割する必要がある.

\section{(4)離散値から近似関数を作成する方法}

$Z^{\prime}-\alpha$ 座標 $(Z$ のみ変数変換) でIndicatrix 関数を求め, 離散值から 近似関数を作成する.この場合は, $Z^{\prime}, \alpha_{s}, \alpha$ の三変数で近似関数を 求める必要がある.さらに, (3)の方法と同様 Indicatrix 関数の值は太陽 位置で大きくなるため, 太陽位置で不連続になること, $\alpha$ により ピークとなる $Z^{\prime}$ が異なる為, 統一的な近似関数を作成するのは困 難であることが考えられる.

以上の検討の結果 (7), (8) 式の積分部分の解析解を求めるには, 通 常の $Z-\alpha$ 座標のまま Gradation 関数, Indicatrix 関数それぞれの解析解 が求まる簡単な近似関数を作成するなどして求めることは不可能で あることがわかった．しかしながら (1)から (4)の方法の検討より，1) 太陽との角距離 $\chi$ の扱い(解析的に解が求まらない)，2)Indicatrix 関数 の太陽位置での関数の不連続性の 2 点を解決することで, 新たな壁 面日射量計算法開発の可能性があると考える. 
そこで，まず1) 太陽との角距離 $\chi$ の扱いに対応するため, (3)の方 法のように, $Z^{\prime}\left(=Z-Z_{s}\right), \alpha^{\prime}\left(=\alpha-\alpha_{s}\right)$ として, 高度方向については 太陽高度を原点に, 方位方向については太陽方位を原点とする座標 に変換することとする．このように座標変換することで，太陽との 角距離 $\chi$ が不要となる. 次に2)Indicatrix 関数の太陽位置での関数の不 連続性に対応するために, $Z_{s}$ の天頂側, 地平線側の二つに分けて Indicatrix 近似関数を求めることとする.

さらに, 壁面日射量計算において, 周辺建物等の遮蔽物を考慮す るには, 周囲の遮蔽物各々の異なる高さに対応できること, 周囲遮 蔽物間の天空非遮蔽部分を取り出せることが必要となる. 都市 キャニオン内の 1 建物など, 周囲遮蔽物（建物）を考慮するシミュ レーションでは, 方位方向については, 街路等により, 遮蔽・非遮 蔽がある程度パターン化して連続することが考えられるが, 遮蔽物 の高さについては, 遮蔽物（建物）により違いがある.このため, 本研究では, $Z^{\prime}$ 方向（高さ方向）については細かく積分区間を求め, $\alpha^{\prime}$ 方向（方位方向）については, $Z^{\prime}, \alpha^{\prime}$ の二重積分のままでは解析 解の求まる簡易な近似関数が求まらないことも考慮し, 天球を適 当な幅に分割する計算法を検討する. 図 2 に座標変換の概要を, 図 3 にIndicatrix 関数の天頂側, 地平線側近似関数の概要を示す.

\section{3 相対日射量の近似}

(7)，(8) 式でみたように，CIE 標準一般天空を用いて，天空放射輝 度分布を考慮した鉛直及び, 水平壁面日射量を求めるには, 以下の 鉛直面, 水平面相詨日射量を求める必要がある。

$I_{\text {vertical_CIE }}^{\prime}=\int_{Z=z_{1}}^{Z=z_{2}} \int_{\alpha=a_{1}}^{\alpha=a_{2}} f(\chi) \varphi(Z) \cdot \sin Z \cos \left(\alpha-\alpha_{r}\right) \cdot \sin Z \cdot d Z d \alpha$

$I_{\text {horizontal_CIE }}=\int_{Z=z_{1}}^{Z=z_{2}} \int_{\alpha=a_{1}}^{\alpha=a_{2}} f(\chi) \varphi(Z) \cdot \cos Z \cdot \sin Z \cdot d Z d \alpha$

ここでI'vertical_CIE は以下のように展開できる.

$I_{\text {vertical_CIE }}$

$=\int_{Z=z_{1}}^{Z=z_{2}} \int_{\alpha=a_{1}}^{\alpha=a_{2}} f(\chi) \varphi(Z) \cdot \sin Z\left(\cos \alpha_{r} \cos \alpha+\sin \alpha_{r} \sin \alpha\right) \cdot \sin Z \cdot d Z d \alpha$

$=\cos \alpha_{r} \times \int_{Z=z_{1}}^{Z=z_{2}} \int_{\alpha=a_{1}}^{\alpha=a_{2}} f(\chi) \varphi(Z) \cdot \sin Z \cos \alpha \cdot \sin Z \cdot d Z d \alpha$

$$
+\sin \alpha_{r} \times \int_{Z=z_{1}}^{Z=z_{2}} \int_{\alpha=a_{1}}^{\alpha=a_{2}} f(\chi) \varphi(Z) \cdot \sin Z \sin \alpha \cdot \sin Z \cdot d Z d \alpha
$$

座標変換を行い, $Z^{\prime}$ の積分で解析解が求まる近似関数を求め, $\alpha^{\prime}$ 方向については天球を適当な幅に分割し，この分割部分ごとに解析 的に求めた相対日射量を合計する.この様な計算を考えると，(10), (11)式は以下のように表せる.

$$
\begin{aligned}
& I_{\text {vertical }}^{\prime} C I E \\
& =\cos \alpha_{r} \times \sum_{i=1}^{n}\left\{\Delta \alpha^{\prime} \times \cos \left(\alpha^{\prime}+\alpha_{s}\right)\right. \\
& \left.\quad \times \int_{Z^{\prime}}^{Z^{\prime}=z_{2}-Z_{1}-Z_{s}} f\left(Z^{\prime}, \alpha^{\prime}, Z_{s}\right) \varphi\left(Z^{\prime}\right) \sin ^{2}\left(Z^{\prime}+Z_{s}\right) d Z^{\prime}\right\} \\
& +\sin \alpha_{r} \times \sum_{i=1}^{n}\left\{\Delta \alpha^{\prime} \times \sin \left(\alpha^{\prime}+\alpha_{s}\right)\right. \\
& \left.\quad \times \int_{Z^{\prime}}^{Z^{\prime}=z_{2}-Z_{s}} f\left(Z^{\prime}, \alpha^{\prime}, Z_{s}\right) \varphi\left(Z^{\prime}\right) \sin ^{2}\left(Z^{\prime}+Z_{s}\right) d Z^{\prime}\right\} \\
& I_{\text {horizontal } C I E}^{\prime} \quad \sum_{i=1}^{n} \Delta \alpha^{\prime} \times \int_{Z^{\prime}=z_{1}-Z_{s}}^{Z^{\prime}=z_{2}-Z_{s}} f\left(Z^{\prime}, \alpha^{\prime}, Z_{s}\right) \varphi\left(Z^{\prime}\right) \cos \left(Z^{\prime}+Z_{s}\right) \cdot \sin \left(Z^{\prime}+Z_{s}\right) \cdot d Z^{\prime}
\end{aligned}
$$
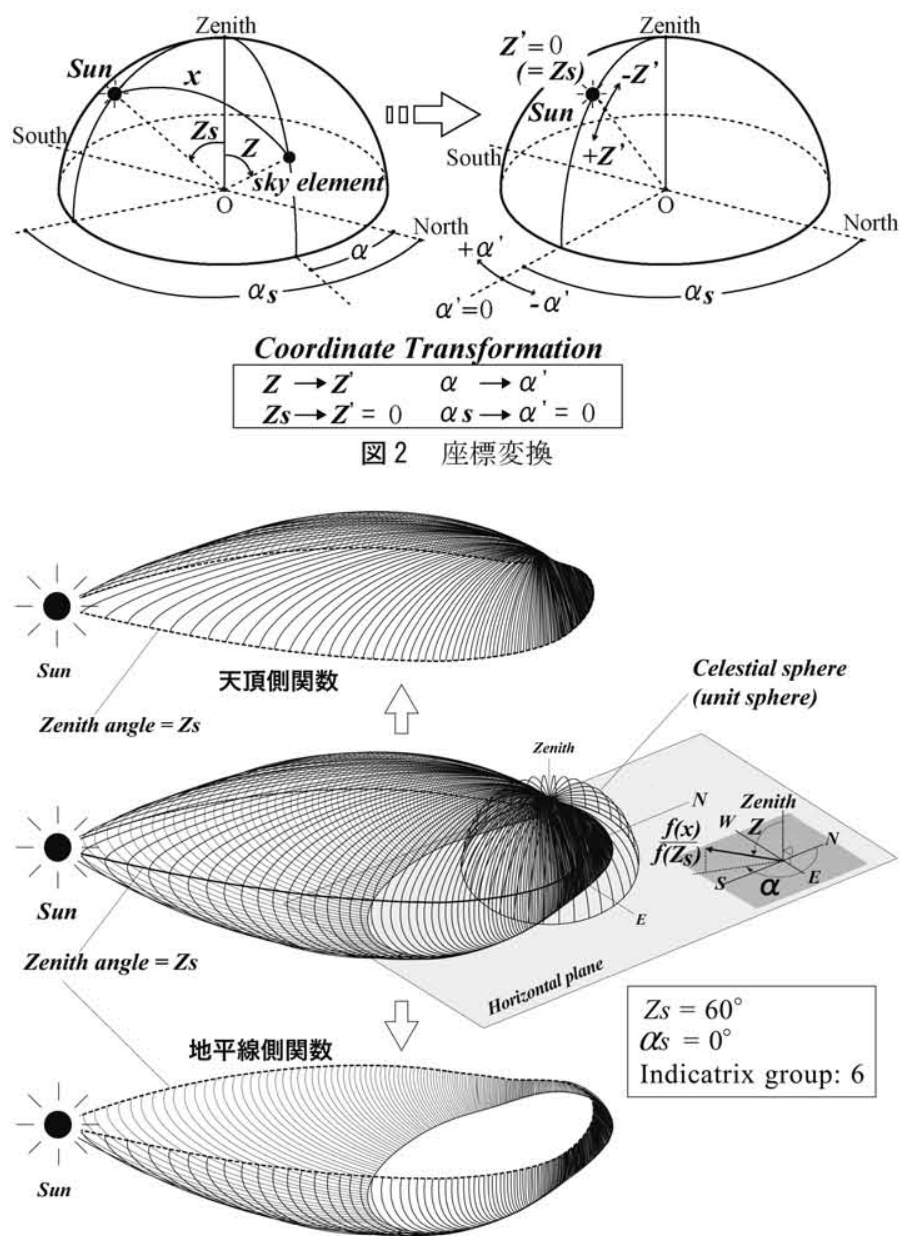

図 3 Indicatrix 天頂側 - 地平線側近似関数の概要

ここで, $\Delta \alpha^{\prime}$ は $\alpha^{\prime}$ の分割幅 [rad], $n$ は $\alpha^{\prime}$ 方向の分割個数

さらに, 天頂及び地平線側関数に分離すると以下の様になる.

$I_{\text {vertical_ClE }}$

$=\cos \alpha_{r} \sum_{i=1}^{n} \Delta \alpha^{\prime} \cos \left(\alpha^{\prime}+\alpha_{s}\right) \int_{Z^{\prime}=0}^{Z^{\prime}=z_{2}-Z_{s}} f_{\alpha^{\prime}}^{g}\left(Z^{\prime}, \alpha^{\prime}, Z_{s}\right) \varphi\left(Z^{\prime}\right) \sin ^{2}\left(Z^{\prime}+Z_{s}\right) d Z^{\prime}$

$+\cos \alpha_{r} \sum_{i=1}^{n} \Delta \alpha^{\prime} \cos \left(\alpha^{\prime}+\alpha_{s}\right) \int_{Z^{\prime}=z_{1}-Z_{s}}^{Z^{\prime}=0} f_{\alpha^{\prime}}^{a}\left(Z^{\prime}, \alpha^{\prime}, Z_{s}\right) \varphi\left(Z^{\prime}\right) \sin ^{2}\left(Z^{\prime}+Z_{s}\right) d Z^{\prime}$

$+\sin \alpha_{r} \sum_{i=1}^{n} \Delta \alpha \alpha^{\prime} \sin \left(\alpha^{\prime}+\alpha_{s}\right) \int_{Z^{\prime}=0}^{Z^{\prime}=z_{2}-Z_{s}} f_{\alpha^{\prime}}^{g}\left(Z^{\prime}, \alpha^{\prime}, Z_{s}\right) \varphi\left(Z^{\prime}\right) \sin ^{2}\left(Z^{\prime}+Z_{s}\right) d Z^{\prime}$

$+\sin \alpha_{r} \sum_{i=1}^{n} \Delta \alpha^{\prime} \sin \left(\alpha^{\prime}+\alpha_{s}\right) \int_{Z^{\prime}=z_{1}-Z_{s}}^{Z^{\prime}=0} f_{\alpha^{\prime}}^{a}\left(Z^{\prime}, \alpha^{\prime}, Z_{s}\right) \varphi\left(Z^{\prime}\right) \sin ^{2}\left(Z^{\prime}+Z_{s}\right) d Z^{\prime}$

I'horizontal_CIE

$=\sum_{i=1}^{n} \Delta \alpha^{\prime} \times \int_{Z^{\prime}=0}^{Z^{\prime}=z_{2}-Z_{s}} f_{\alpha^{\prime}}^{g}\left(Z^{\prime}, \alpha^{\prime}, Z_{s}\right) \varphi\left(Z^{\prime}\right) \cos \left(Z^{\prime}+Z_{s}\right) \cdot \sin \left(Z^{\prime}+Z_{s}\right) \cdot d Z^{\prime}$

$+\sum_{i=1}^{n} \Delta \alpha^{\prime} \times \int_{Z^{\prime}=z_{1}-Z_{s}}^{Z^{\prime}=0} f_{\alpha^{\prime}}^{a}\left(Z^{\prime}, \alpha^{\prime}, Z_{s}\right) \varphi\left(Z^{\prime}\right) \cos \left(Z^{\prime}+Z_{s}\right) \cdot \sin \left(Z^{\prime}+Z_{s}\right) \cdot d Z^{\prime}$

つまり $f_{\alpha^{\prime}}^{a}\left(Z^{\prime}, \alpha^{\prime}, Z_{s}\right) \varphi\left(Z^{\prime}\right), f_{\alpha^{\prime}}^{g}\left(Z^{\prime}, \alpha \alpha^{\prime}, Z_{s}\right) \varphi\left(Z^{\prime}\right)$ を解析解が求まる式 で近似し, 以下の不定積分を求めておけば良い.

$$
\begin{aligned}
& f_{\alpha^{\prime}}^{a}\left(Z^{\prime}, \alpha^{\prime}, Z_{s}\right) \varphi\left(Z^{\prime}\right) \sin ^{2}\left(Z^{\prime}+Z_{s}\right) \\
& f_{\alpha^{\prime}}^{g}\left(Z^{\prime}, \alpha^{\prime}, Z_{s}\right) \varphi\left(Z^{\prime}\right) \sin ^{2}\left(Z^{\prime}+Z_{s}\right) \\
& f_{\alpha^{\prime}}^{a}\left(Z^{\prime}, \alpha^{\prime}, Z_{s}\right) \varphi\left(Z^{\prime}\right) \cos \left(Z^{\prime}+Z_{s}\right) \cdot \sin \left(Z^{\prime}+Z_{s}\right) \\
& f_{\alpha^{\prime}}^{g}\left(Z^{\prime}, \alpha^{\prime}, Z_{s}\right) \varphi\left(Z^{\prime}\right) \cos \left(Z^{\prime}+Z_{s}\right) \cdot \sin \left(Z^{\prime}+Z_{s}\right)
\end{aligned}
$$


天頂側関数 $f_{\alpha^{\prime}}^{a}$, 地平線側関数 $f_{\alpha^{\prime}}^{g}$ が同様な形で近似できるなら ば, その係数を入れ替えるだけでよく, 結果として, 以下の 2 式 について, 解析解が求まる式で近似すればよいことになる.

$$
\begin{aligned}
& f_{\alpha^{\prime}}^{a(g)}\left(Z^{\prime}, \alpha^{\prime}, Z_{s}\right) \varphi\left(Z^{\prime}\right) \sin ^{2}\left(Z^{\prime}+Z_{s}\right) \\
& f_{\alpha^{\prime}}^{a(g)}\left(Z^{\prime}, \alpha^{\prime}, Z_{s}\right) \varphi\left(Z^{\prime}\right) \cos \left(Z^{\prime}+Z_{s}\right) \cdot \sin \left(Z^{\prime}+Z_{s}\right)
\end{aligned}
$$

本研究では, (20), (21) 式から Gradation 関数, Indicatrix 関数それぞ れを分離して, 解析解の求まる近似関数を見出すこととする。こ れは Gradation 関数, Indicatrix 関数の掛け合わさった式を近似するの ではなく, Gradation 関数, Indicatrix 関数各々の近似関数を求めるこ とで, より精度の高い近似関数を求められると考える為である.

\section{3. 天空放射輝度分布を考慮した壁面日射量計算法}

\subsection{Gradation 関数の近似}

解析解の求まる一般的な関数を当てはめてゆき, 誤差の検討を 行って近似関数 $\hat{\varphi}\left(Z^{\prime}\right)$ を決定した. Gradation 関数については，以下の 式で近似することとした. 表 1 に倸数 $g_{1}, g_{2}, g_{3}$ を示す.

$$
\hat{\varphi}\left(Z^{\prime}\right)=g_{1} \times g_{2}{ }^{Z^{\prime}}+g_{3}
$$

図 4 に示すように, グループI の地平線に近い領域 $\left(Z^{\prime}=90^{\circ}\right.$ 近傍 $)$ で, Gradation 関数 $\varphi(Z)$ と近似関数 $\hat{\varphi}\left(Z^{\prime}\right)$ にやや違いが見られる. 図 5 に各高度 $Z^{\prime}$ における, 近似関数の Gradation 関数に対する相対誤差を 示す. 図 4 で見たようにグループI の地平線に近い領域でやや大き く，10\%超えるところが見られるが，それ以外では概ね $\pm 5 \%$ 以内 である.これから (22) 式でGradation 関数が精度良く近似されているこ とがわかる. 地平線近傍の低高度の天空要素については, 周囲遮蔽 物を考慮する壁面日射量計算では, 建物等により遮蔽されることが 多いため, 他の高度と比心゙, 近似精度の低下は無視できるものと考 える. なお Gradation 関数は $Z$ のみの関数であり Indicatrix 関数のように 太陽方位 $\alpha_{s}$, 天頂角 $Z_{s}$ によらない. 近似関数の場合は, 座標変換 により高度方向の原点は時刻ごとに変化するが, $Z_{s}$ が変化しても近 似関数を $Z_{s}$ だけ平行移動してやるだけでよい。例えば図 4，5 は $Z_{s}=0^{\circ}$ の場合を示しているが, $Z_{s}=40^{\circ}$ の場合には図 4,5 の $\hat{\varphi}\left(Z^{\prime}\right)$ の マーカー, 相対誤差のマーカーで表すグラフをそのまま左に 4 目盛 ずらしてやればよい，表 2 に近似関数の Gradation 関数に対する\%RMSE を示す. 図 5 の相対誤差が，各高度における誤差であるのに対し，こ れは, Gradation 関数に対して, 近似関数の各グループがそれぞれ全 体でどの程度の誤差があるかを示している．これも $5 \%$ 以下である，

次に, Gradation 関数の分布のみを考慮した場合の, 鉛直面相対日 射量 $I^{\prime}$ vertical_GRA, 水平面相対日射量 $I^{\prime}$ horizontal_GRA を求め, 近似関

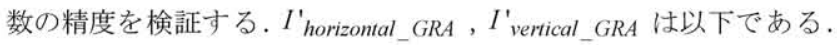

$$
\begin{aligned}
& I_{\text {vertical_GRA }}^{\prime} \text { GRA } \\
& \quad=\cos \alpha_{r} \times \sum_{i=1}^{n} \Delta \alpha^{\prime} \times \cos \left(\alpha^{\prime}+\alpha_{s}\right) \times \int_{Z^{\prime}=z_{1}-Z_{s}}^{Z^{\prime}=z_{2}-Z_{s}} \hat{\varphi}\left(Z^{\prime}\right) \sin ^{2}\left(Z^{\prime}+Z_{s}\right) d Z^{\prime} \\
& +\sin \alpha_{r} \times \sum_{i=1}^{n} \Delta \alpha^{\prime} \times \sin \left(\alpha^{\prime}+\alpha_{s}\right) \times \int_{Z^{\prime}=z_{1}-Z_{s}}^{Z^{\prime}=z_{2}-Z_{s}} \hat{\varphi}\left(Z^{\prime}\right) \sin ^{2}\left(Z^{\prime}+Z_{s}\right) d Z^{\prime} \\
& I_{\text {horizontal_GRA }}=\sum_{i=1}^{n} \Delta \alpha^{\prime} \times \int_{Z^{\prime}=z_{1}-Z_{s}}^{Z^{\prime}=z_{2}-Z_{s}} \hat{\varphi}\left(Z^{\prime}\right) \cos \left(Z^{\prime}+Z_{s}\right) \cdot \sin \left(Z^{\prime}+Z_{s}\right) d Z^{\prime}
\end{aligned}
$$

(23), (24) 式より求めた相対日射量と, 数值積分により求めた相対 日射量注4)の比較を行う（図6）。相対日射量はよく一致している.
表 1 Gradation 近似関数の係数

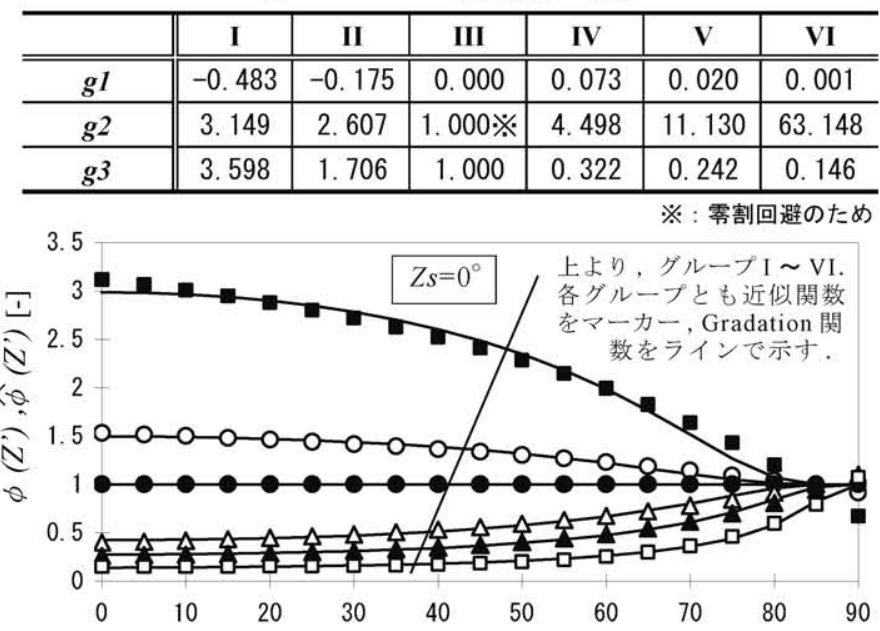

図 4 Gradation 関数と近似関数の比較 $\left(Z s=0^{\circ}\right.$ の場合)

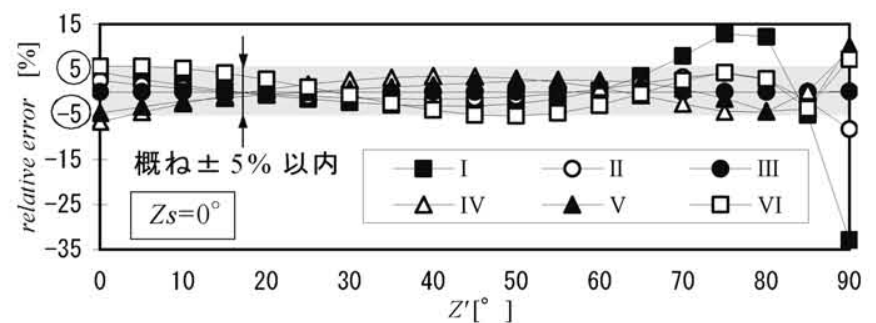

図 5 Gradation 近似関数の相対誤差 $\left(Z s=0^{\circ}\right.$ の場合 $)$

表 2 Gradation 近似関数の\%RMSE

\begin{tabular}{c||c|c|c|c|c|c}
\hline & I & II & III & IV & V & VI \\
\hline \hline \%RMSE & 4.22 & 1.95 & 0.00 & 3.79 & 4.06 & 5.01 \\
\hline
\end{tabular}

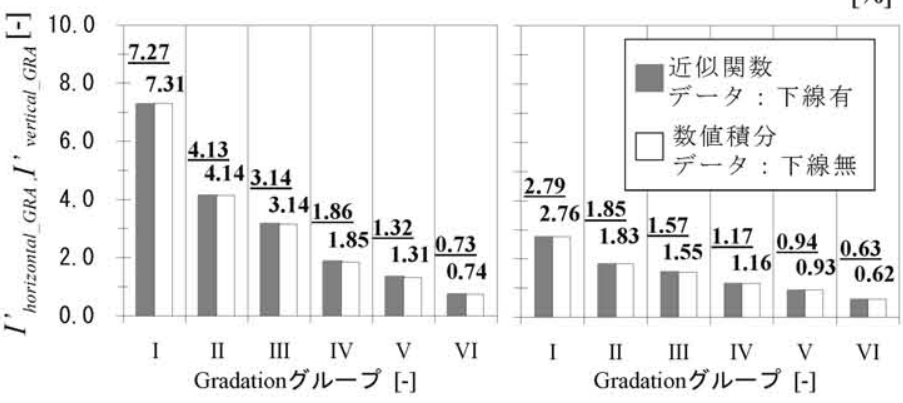

a) 水平面 b) 鉛直面

図 6 相詨日射量(Gradation 関数) の比輷

表 3 相対日射量 (Gradation 関数) の相対誤差

\begin{tabular}{c||c|c|c|c|c|c}
\hline & I & II & III & IV & V & VI \\
\hline \hline 水平面 & -0.56 & -0.23 & 0.01 & 0.65 & 0.61 & -0.87 \\
\hline 鉛直面 & 1.06 & 1.14 & 1.13 & 1.32 & 1.80 & 2.32 \\
\hline \multicolumn{6}{c|}{}
\end{tabular}

表 3 に示すとおり数值積分に対する相対誤差は, 水平面では $1 \%$ 未 満, 鉛直面でも最大で $2.32 \%$ (Gradation グループ: VI) と小さい.これか らも近似関数 (22) 式が精度のよい近似となっていることがわかる.

\subsection{Indicatrix 関数の近似}

Indicatrix 関数は, 天頂側, 地平線側それぞれ以下の式で近似する.

天頂側 : $\quad \hat{f}_{\alpha^{\prime}}^{a}\left(Z^{\prime}, \alpha^{\prime}, Z_{s}\right)=f_{a, 1} \times \exp \left(f_{a, 2} Z^{\prime}\right)+f_{a, 3}$

地平線側： $\hat{f}_{\alpha^{\prime}}^{g}\left(Z^{\prime}, \alpha^{\prime}, Z_{s}\right)=f_{g, 1} \times \exp \left(f_{g, 2} Z^{\prime}\right)+f_{g, 3}$

Indicatrix 関数は, $Z^{\prime}, \alpha^{\prime}, Z_{s}$ の関数である. まず近似関数の係数を 
$Z_{s}, \alpha^{\prime}$ の関数として表すことを考え検討を行ったが, $Z_{s}$ により係数 $f_{a, 1}, f_{a, 2}, f_{a, 3}, f_{g, 1}, f_{g, 2}, f_{g, 3}$ の性状が異なり関数を求めること ができないことがわかった ${ }^{18}$. このためIndicatrix のグループごとに天 頂側, 地平線側近似関数それぞれの係数を， $Z_{s} ， \alpha^{\prime}$ に関するパラ メータ表として整理しておき, 壁面日射量計算の際には, このパラ メータ表から, 対応する係数を取り出してきて計算することとす る. 表 4 に近似関数のパラメータ表 (Indicatrix グループ: $6, f_{a, 1}, f_{g, 1}$ の夕抜粋) ${ }^{21}$, 洋5) を示す. 図 7 にIndicatrix 関数 $f(\chi)$ と, 近似関数 $\mathrm{I}^{\circ}$ $\widehat{f}_{\alpha^{\prime}}^{a}\left(Z^{\prime}, \alpha^{\prime}, Z_{s}\right)$ および $\hat{f}_{\alpha^{\prime}}^{g}\left(Z^{\prime}, \alpha^{\prime}, Z_{s}\right)$ の比較 (Indicatrix グループ: 6 , $\left.Z^{\prime}=30^{\circ}\right)$ を示す. 太陽位置に近い領域で, Indicatrix 関数と近似関数 にやや相違はあるものの, 精度良く近似している. 図 8 にIndicatrix 関 数に対する近似関数の誤差を示す. 各Indicatrix グループで, $Z_{s}$ それぞ れについて, $\alpha^{\prime}$ ごとの\%RMSE（図７の各曲線とマーカーとの\%RMSE) を求め, 各 $\alpha^{\prime}$ で\%RMSEが中間值となる $Z_{s}$ の\%RMSEを示している. これより Indicatrix 各グループの方位による誤差の違いを知ることが できる. 太陽方位近傍から $90^{\circ}$ の範囲で，\%RMSE はやや大きくな る. しかし, Indicatrix グループ1〜3では, $3 \%$ を超えることはなく, グループ 4, 5 ではそれぞれ最大 $3.53 \%, 4.15 \%$ ，\%RMSEの一番大きく なるグループ 6 でも最大 $4.44 \%$ であり, 近似誤差は小さい. これよ り近似関数 $(25),(26)$ は精度の良い近似であると言える.

次に, Gradation 関数の場合と同様に, Indicatrix 関数のみの分布を考 慮した, 以下の (27), (28) 式で表される鉛直面, 水平面相対日射量と 数值積分による相対日射量との比較を行う.

$$
\begin{aligned}
& I_{\text {vertical_IND }}^{\prime} \\
& =\cos \alpha_{r} \sum_{i=1}^{n} \Delta \alpha^{\prime} \cos \left(\alpha^{\prime}+\alpha_{s}\right) \int_{Z^{\prime}=0}^{Z^{\prime}=z_{2}-Z_{s}} \widehat{f}_{\alpha^{\prime}}^{g}\left(Z^{\prime}, \alpha^{\prime}, Z_{s}\right) \sin ^{2}\left(Z^{\prime}+Z_{s}\right) d Z^{\prime} \\
& +\cos \alpha_{r} \sum_{i=1}^{n} \Delta \alpha^{\prime} \cos \left(\alpha^{\prime}+\alpha_{s}\right) \int_{Z^{\prime}=z_{1}-Z_{s}}^{Z^{\prime}=0} \widehat{f}_{\alpha^{\prime}}^{a}\left(Z^{\prime}, \alpha^{\prime}, Z_{s}\right) \sin ^{2}\left(Z^{\prime}+Z_{s}\right) d Z^{\prime} \\
& +\sin \alpha_{r} \sum_{i=1}^{n} \Delta \alpha \alpha^{\prime} \sin \left(\alpha^{\prime}+\alpha_{s}\right) \int_{Z^{\prime}=0}^{Z^{\prime}=z_{2}-Z_{s}} \widehat{f}_{\alpha^{\prime}}^{g}\left(Z^{\prime}, \alpha^{\prime}, Z_{s}\right) \sin ^{2}\left(Z^{\prime}+Z_{s}\right) d Z^{\prime} \\
& +\sin \alpha_{r} \sum_{i=1}^{n} \Delta \alpha \alpha^{\prime} \sin \left(\alpha^{\prime}+\alpha_{s}\right) \int_{Z^{\prime}=z_{1}-Z_{s}}^{Z^{\prime}=0} \hat{f}_{\alpha^{\prime}}^{a}\left(Z^{\prime}, \alpha^{\prime}, Z_{s}\right) \sin ^{2}\left(Z^{\prime}+Z_{s}\right) d Z^{\prime} \\
& \quad=\sum_{i=1}^{n} \Delta \alpha^{\prime} \times \int_{Z^{\prime}=0}^{Z^{\prime}=z_{2}-Z_{s}} \widehat{f}_{\alpha^{\prime}}^{g}\left(Z^{\prime}, \alpha^{\prime}, Z_{s}\right) \cos \left(Z^{\prime}+Z_{s}\right) \cdot \sin \left(Z^{\prime}+Z_{s}\right) \cdot d Z^{\prime} \\
& \quad+\sum_{i=1}^{n} \Delta \alpha^{\prime} \times \int_{Z^{\prime}=z_{1}-Z_{s}}^{Z^{\prime}=0} \hat{f}_{\alpha^{\prime}}^{a}\left(Z^{\prime}, \alpha^{\prime}, Z_{s}\right) \cos \left(Z^{\prime}+Z_{s}\right) \cdot \sin \left(Z^{\prime}+Z_{s}\right) \cdot d Z^{\prime}
\end{aligned}
$$

図 9 に, 水平面における近似関数, 数值積分それぞれにより求め た相対日射量の比較を示す. 図 9a)をみると, 各 $Z_{s}$ で相対日射量は よく一致しているのがわかる. また図 $9 b$ ) に示すとおり, 数值積分 による相対日射量に対する相対誤差は, $\pm 1 \%$ 未満であり，精度良く 近似できていることがわかる.

図 10a) に, 天頂角 $Z_{s}$ が $40^{\circ}$ の場合の鉛直面相対日射量の比較を示 す. $I_{\text {vertical_IND }}{ }^{\prime}$ については天頂角 $Z_{s}$ の違いにより值が変化するた め, 中間的な天頂角 $Z_{s}\left(=40^{\circ}\right)$ の場合を例として示している. この場 合も近似関数と数值積分の結果がよく一致している. 図 $10 \mathrm{~b})$ に, 相 対誤差を太陽方位に対する壁面の相対方位角 $\left|\alpha_{s}-H_{a}\right|$ ごとに示す. 概ね $1 \%$ 未満となっており精度良い相対日射量を求めていることが わかる. Indicatrix グループ 3, 4 の相対方位角が大きくなる場合に $1.3 \%$ 程度(最大 $1.33 \%$ : Indicatrix グループ $4,\left|\alpha_{s}-H_{a}\right|=180^{\circ}$ ) とわずかに大き
表 4 Indicatrix 天頂側 - 地平線側近似関数の係数 (Indicatrix group:6 $f_{a, 1}, f_{g, 1}$ の)抜粋)

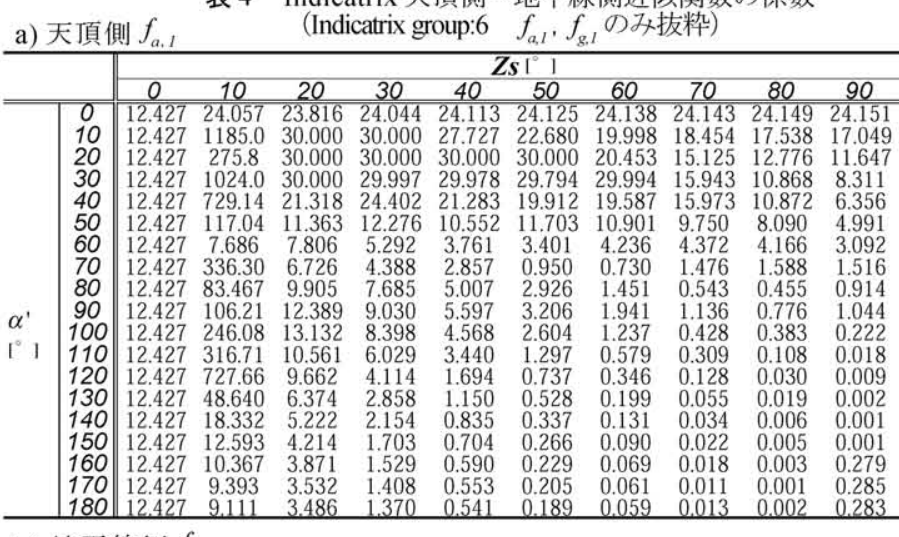

b) 地平線側 $f_{g, l}$

\begin{tabular}{|c|c|c|c|c|c|c|c|c|c|c|c|}
\hline & \multicolumn{10}{|c|}{ Zs $\quad 1^{\circ} \quad$ ] } \\
\hline & & 0 & 10 & 20 & 30 & 40 & 50 & 60 & 70 & 80 & 90 \\
\hline \multirow{6}{*}{ 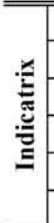 } & 1 & 0.87 & 0.87 & 0.87 & 0.87 & 0.87 & 0.87 & 0.87 & 0.87 & 0.87 & 0.87 \\
\hline & 2 & 0.70 & 0.75 & 0.84 & 0.97 & 1.13 & 1.23 & 1.29 & 1.32 & 1.30 & 1.23 \\
\hline & 3 & 0.58 & 0.74 & 1.02 & 1.31 & 1.60 & 1.77 & 1.87 & 1.88 & 1.82 & 1.63 \\
\hline & 4 & 0.51 & 0.77 & 1.27 & 1.72 & 2.11 & 2.37 & 2.52 & 2.54 & 2.43 & 2.17 \\
\hline & 5 & 0.39 & 0.85 & 1.53 & 2.11 & 2.59 & 2.93 & 3.14 & 3.20 & 3.13 & 2.87 \\
\hline & 6 & 0.23 & 0.97 & 1.81 & 2.52 & 3.08 & 3.49 & 3.76 & 3.88 & 3.86 & 3.69 \\
\hline
\end{tabular}
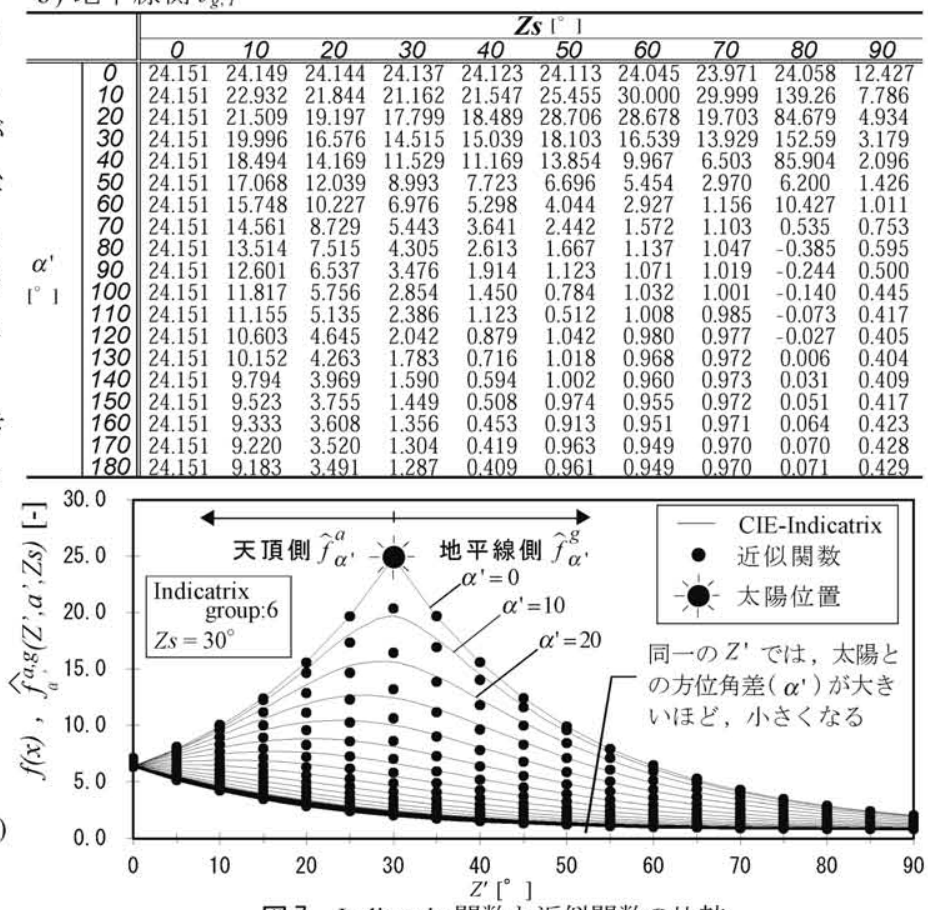

図 7 Indicatrix 関数と近似関数の比較

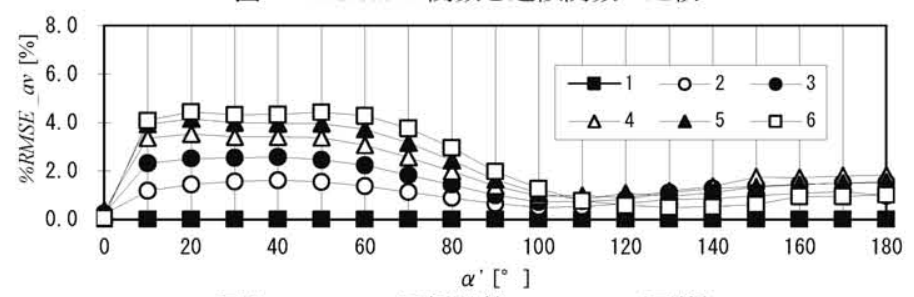

図 8 Indicatrix 近似関数の\%RMSE (平均)

表 5 鉛直面相対日射量 (Indicatrix 関数) の\%RMSE

くなるが，図 10a)に示すとおりこの時の相対日射量 $I^{\prime}$ vertical_IND 自体 が小さな值であり, 問題となるものではないと判断した. 表 5 に相 対日射量の\%RMSE を示す. 図 10b) の相対誤差が特定の天頂角におけ る相対方位角ごとの誤差を示すのに対し, Indicatrix グループそれぞれ 


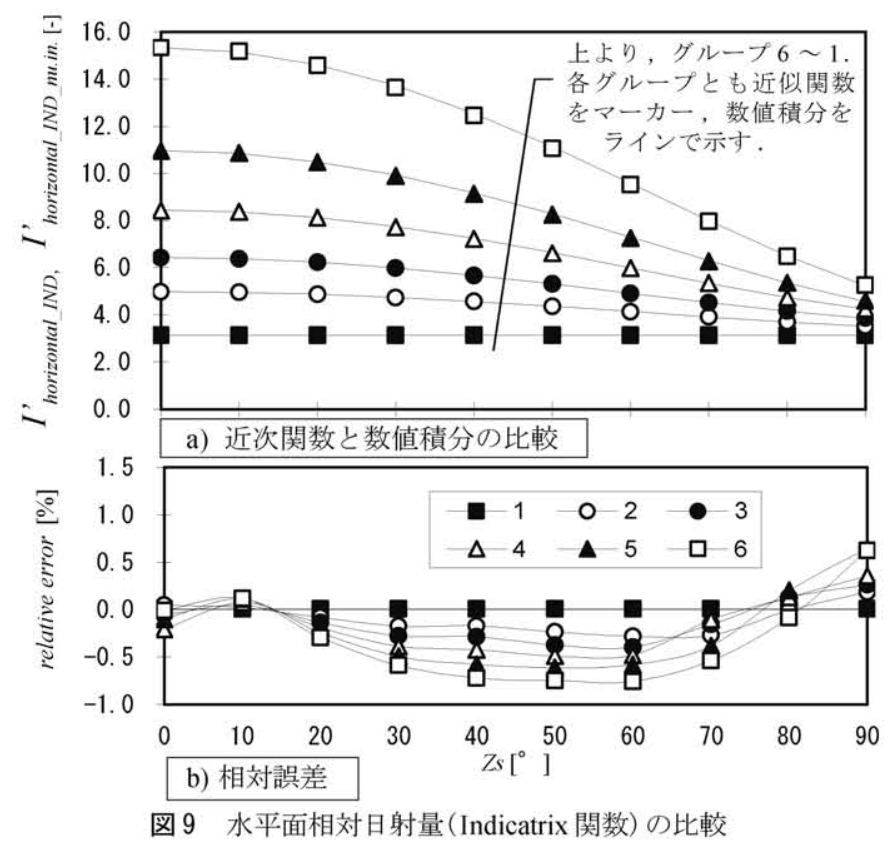

の分布を考慮した相対日射量の各 $Z_{S}$ におけるす心゙ての相対方位角 での誤差（各 $Z_{s}$ における, 図 10a)の各曲線とマーカーとの\%RMSE） である. \%RMSE はグループ 6 の $Z^{\prime}=70^{\circ}$ で最大值を示すものの, こ の場合でも $3.88 \%$ と十分小さい。これからも近似関数 (25), (26) は精 度のよい近似であり, これにより精度良く相対日射量を求めること ができる.

\section{3 壁面相対日射量の比較}

(14), (15) 式に近似関数 $\hat{\varphi}\left(Z^{\prime}\right), \hat{f}_{\alpha^{\prime}}^{a}, \hat{f}_{\alpha^{\prime}}^{g}$ を用いて求めた鉛直面相対 日射量および水平面相対日射量と, 数值積分により求めた鉛直面お よび水平面相対日射量との比較を行うことで, 提案する壁面日射量 計算法の有効性を検証する.

図 11 に, 水平面における, 近似関数, 数值積分それぞれにより求 めた相対日射量の比較を示す. 図 11 a) をみると, 各天頂角で相対日 射量はよく一致しているのがわかる. また図 $11 \mathrm{~b}$ ) をみると, 数值積 分による相対日射量に対する相対誤差は, 天空タイプ 14, 15 で太陽

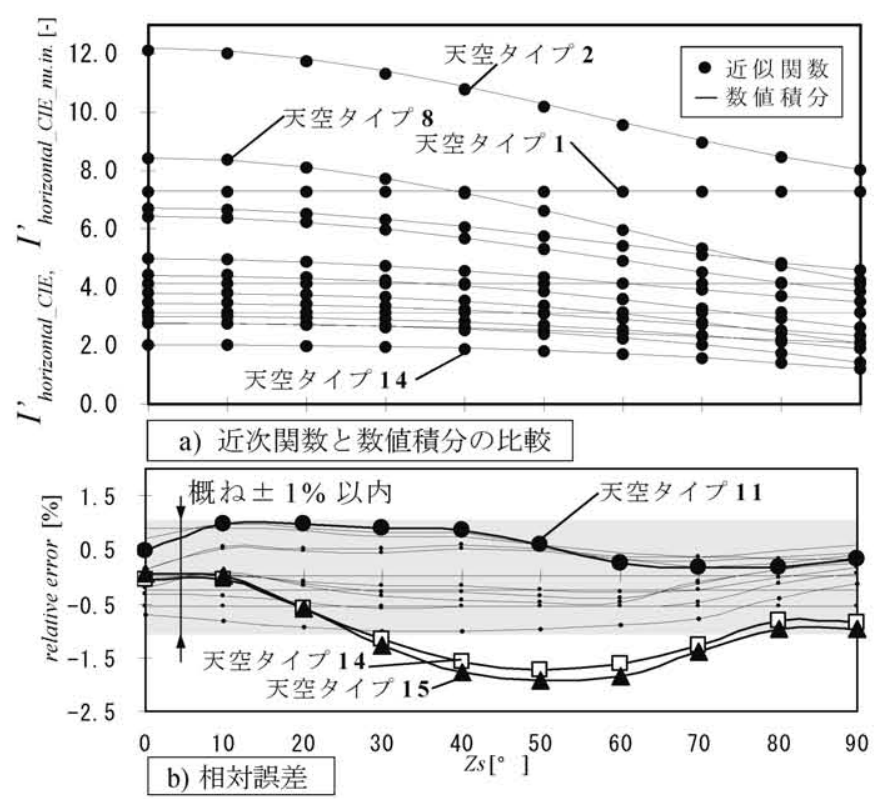

図 11 水平面相対日射量の比較

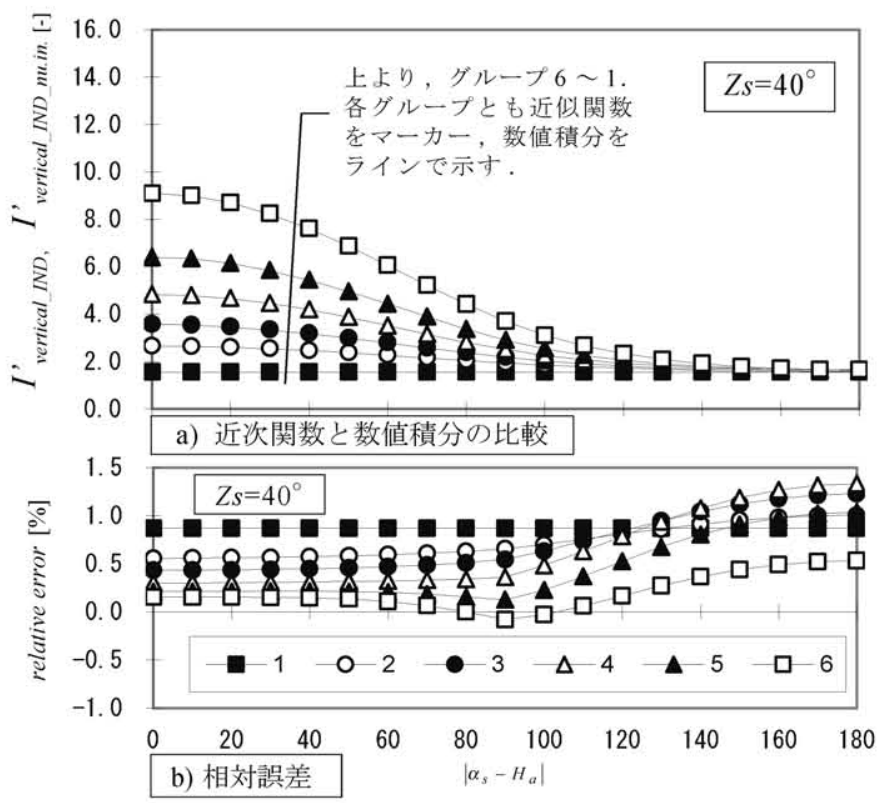

図 10 鉛直面相対日射量 (Indicatrix 関数) の比較 $\left(Z s=40^{\circ}\right)$

の天頂角が $30 \sim 70^{\circ}$ の場合にやや大きくなり, 最大で-1.93\% (天空 タイプ: $\left.15, Z_{s}=50^{\circ}\right)$ となるものの, 概ね $\pm 1 \%$ 未満であり, Gradation 関数と Indicatrix 関数を組み合わせた場合でも精度良く近似できてい ることがわかる。

図 12a)に, 鉛直面相対日射量の比較を示す. $I^{\prime}$ verrical_CIE について は $I_{\text {vertical_IND }}^{\prime}$ 同様天頂角 $Z_{S}$ の違いにより值が変化するため, 天頂 角 $Z_{s}=40^{\circ}$ の場合を示す. 各天空タイプでよく一致しているのがわ かる. 図 12b)に, 相対誤差を相対方位角 $\left|\alpha_{s}-H_{a}\right|$ ごとに示す. 概ね $1.5 \%$ 未満となり精度良く相対日射量を求められている. 天空タイプ $13 ， 14$ の相対方位角が大きくなる場合に $1.5 \%$ を超えるものが見られ たが，最大でも $1.76 \%$ (天空タイプ $13,\left|\alpha_{s}-H_{a}\right|=180^{\circ}$ ) であり，相対 誤差は十分小さい. 表 6 に I'vertical_CIE の\%RMSE を示す.これは, Indicatrix の場合（表 5) と同様, 天空タイプそれぞれの分布を考虑し た相対射量の各 $Z_{s}$ におけるすべての相対方位角での誤差である. \%RMSE は天空タイプ 15 の $Z^{\prime}=90^{\circ}$ で最大值 $4.93 \%$ であり， $5 \%$ を超え

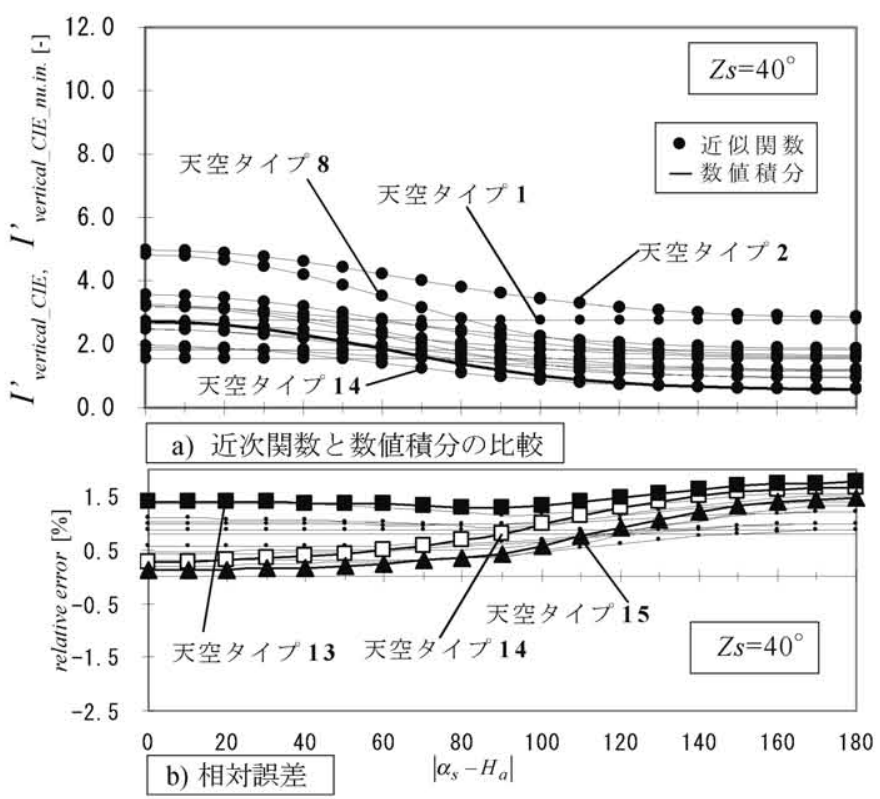

図 12 鉛直面相対日射量の比較 $\left(Z s=40^{\circ}\right.$ の場合) 
表 6 鉛直面相対日射量の\%RMSE

\begin{tabular}{|c|c|c|c|c|c|c|c|c|c|c|c|}
\hline & \multicolumn{10}{|c|}{$Z s\left[{ }^{\circ}\right]$} \\
\hline & & 0 & 10 & 20 & 30 & 40 & 50 & 60 & 70 & 80 & 90 \\
\hline \multirow{15}{*}{$\frac{\Xi}{\frac{2}{2}}$} & 1 & 0.81 & 0.81 & 0.81 & $\overline{0.81}$ & $\overline{0.81}$ & $\overline{0.81}$ & 0.81 & 0.81 & 0.81 & $\overline{0.81}$ \\
\hline & 2 & 0.37 & 0.49 & 0.66 & 0.87 & 1.09 & 1.21 & 1.28 & 1.30 & 1.29 & 1.22 \\
\hline & 3 & 0.89 & 0.89 & 0.89 & 0.89 & 0.89 & 0.89 & 0.89 & 0.89 & 0.89 & 0.89 \\
\hline & 4 & 0.60 & 0.67 & 0.78 & 0.93 & 1.13 & 1.24 & 1.31 & 1.34 & 1.32 & 1.25 \\
\hline & 5 & 0.87 & 0.87 & 0.87 & 0.87 & 0.87 & 0.87 & 0.87 & 0.87 & 0.87 & 0.87 \\
\hline & 6 & 0.70 & 0.75 & 0.84 & 0.97 & 1.14 & 1.24 & 1.31 & 1.33 & 1.31 & 1.23 \\
\hline & 7 & 0.58 & 0.74 & 1.02 & 1.32 & 1.62 & 1.81 & 1.92 & 1.93 & 1.85 & 1.64 \\
\hline & 8 & 0.51 & 0.77 & 1.28 & 1.76 & 2.17 & 2.44 & 2.60 & 2.62 & 2.48 & 2.18 \\
\hline & 9 & 1.05 & 1.06 & 1.12 & 1.21 & 1.31 & 1.37 & 1.40 & 1.42 & 1.41 & 1.33 \\
\hline & 10 & 1.15 & 1.06 & 1.27 & 1.49 & 1.72 & 1.85 & 1.94 & 1.98 & 1.93 & 1.75 \\
\hline & 11 & 1.36 & 1.03 & 1.45 & 1.85 & 2.19 & 2.42 & 2.58 & 2.68 & 2.59 & 2.32 \\
\hline & 12 & 1.74 & 1.07 & 1.45 & 1.88 & 2.27 & 2.55 & 2.69 & 2.75 & 2.75 & 2.59 \\
\hline & 13 & 1.50 & 0.91 & 1.54 & 2.17 & 2.69 & 3.07 & 3.29 & 3.41 & 3.44 & 3.27 \\
\hline & 14 & 1.43 & 0.90 & 1.35 & 1.84 & 2.33 & 2.82 & 3.27 & 3.65 & 4.03 & 4.11 \\
\hline & 15 & 0.72 & 1.47 & 1.84 & 2.35 & 2.91 & 3.43 & 3.91 & 4.33 & 4.76 & 4.93 \\
\hline
\end{tabular}

ない，精度良く相対日射量を求めることができる水準と判断した.

以上より，計算精度を検証した結果，本報で示す天空放射輝度分 布を考虑した壁面日射量計算法は有効であると言える。

\section{4. 計算時間}

解析解の求まる近似関数を定義し, 壁面日射量を計算する手法の 開発を行った。この手法の年間熱負荷計算等への応用を考えるなら ば，より計算時間のかからないものであることが望ましい，そこで, 開発した壁面日射量計算法, 数值積分 (分割幅は高度方向, 方位方 向ともに $\left.1^{\circ}\right)$ の計算時間の比較を行い, 開発した手法の計算時間 についての有効性を確認する.

近似関数を用いて, 天空タイプ15 タイプそれぞれ，遮蔽物の無い 場合の鉛直面相対日射量を計算し，それに要する時間を比較する. 図 13 に計算時間の比較を示す. 鉛直面相対日射量一回の計算に要す る時間は, 数值積分では平均 $4.71 \times 10^{-2}$ 秒, 開発した手法では平均 $8.58 \times 10^{-3}$ 秒である注6)、注7). 開発した壁面日射量計算法の計算時間は, 数值積分による方法に比べ約 $1 / 6$ (平均) と格段に短い。一回の日射 量計算に要する時間は短いが，年間シミュレーションを考えると， 計算時間数, 壁面数により壁面日射量の計算回数は増加し, その計 算時間の違いは無視できないものとなる.なお, 太陽が周囲建物に 遮蔽される場合は, 開発した方法では天頂側近似関数のみ計算すれ ば良い。これからも計算時間短縮が見込める.

以上より, 計算速度について, 近似関数を用いた, 天空放射輝度 分布, 遮蔽物を考慮した壁面日射量計算法は有効であると言える.

\section{5. 結}

天空放射輝度分布, 周囲遮蔽物を考虑した年間熱負荷計算といっ た熱シミュレーションを前提として, CIE 標準一般天空の Gradation 関 数, Indicatrix 関数を解析的に解の求まる簡易な関数で近似すること で, 計算時間の必要となる数值積分等によらない壁面日射量計算法 を開発した。開発した手法を検証し, 以下の知見を得た。

1) 地平線に近い領域や, 太陽近傍でやや違いが見られるグループも あったが, Gradation 関数, Indicatrix 関数ともに精度の高い近似関数 が求められた。

2) Gradation 関数, Indicatrix 関数の近似関数を組み合わせて求めた相対 日射量と数值積分により求めた相対日射量との比較を行った. 水

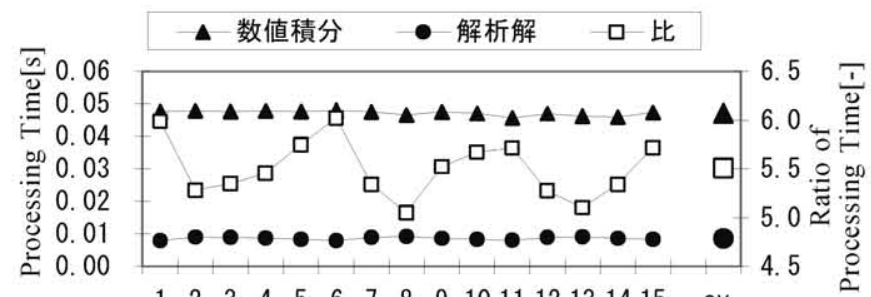

$\begin{array}{llllllllllll}1 & 2 & 3 & 4 & 5 & 6 & 7 & 8 & 9 & 1011 & 12131415 & \text { av. }\end{array}$ SkyType No. [-]

図 13 計算時間

平面では最大でも相対誤差は-1.93\%，鉛直面では \%RMSE4.98\% と 十分小さく，提案した手法により精度良く日射量を計算できるこ とがわかった.

3) 開発した手法, 数值積分それぞれの鉛直面相対日射量計算時間 を比較した. 開発した手法の計算時間は, 数値積分に比べ約 $1 / 6$ と 格段に短い.

以上より, 本報で開発した, 解析解を用いた壁面日射量計算法は, 精度はもちろん, 計算速度の観点からも, 年間熱負荷計算等の熱環 境シミュレーションに応用可能な手法であると考える。

注

注 1)CIE 標準一般天空は, 晴天空から曇天空までの天空状態を 15 の「天空 タイプ(Sky Type)」に分類・規定しモデル化している.この「天空タイ プを規定するパラメータの值は, 天空輝度の実測データを, モデルを構 成する Gradation, Indicatrix 各関数について各々 6 つに分類, 回帰して決 定している. CIE では, この Gradation 関数の 6 つの分類を「グループI $\sim$ VI $($ group I $\sim$ VI $($ ローマ数字) ) 」, Indicatrix 関数の 6 つの分類を「グ ループ1〜6 (group 1〜6 (アラビア数字))」と表記する.

注 2) 本研究では, 建築物は一般的に鉛直面及び水平面から構成されている ものと考え，傾斜面のうち鉛直面及び水平面について検討を行った.

注 3）常に遮蔽のない場合の計算值となるので, あらかじめ各天空タイプ, $Z_{s}$ ごとに, 数值積分により求めて, これを $Z_{s}$ の近似式として定義して おくことで, 計算時間の短縮が図れる. $Z_{s}$ の 1 次, 2 次近似式を求め, 数 值積分による水平面放射照度合計值（遮蔽の無し）と, その 1 次, 2 次 近似式との $\mathrm{R}^{2}$ 值を検討したところ(図 14)，2 次近似で十分な精度を得ら れることを確認した. 表 7 に 2 次の近似式の係数を示寸.

$$
I_{\text {horizontal_ClE_nonshaded }}=j_{1} Z_{s}^{2}+j_{2} Z_{s}+j_{3}
$$

注 4) 数值積分による, Gradation 関数の分布のみを考慮した場合の相対日射 量, Indicatrix 関数の分布のみを考慮した場合の相対日射量, Gradation 関 数, Indicatrix 関数ともに考慮した相対日射量は以下のように, 検討壁面 から可視である天球上の微小面要素(図 15)について放射照度を求め合計 したものとなる．

$$
\begin{aligned}
& I_{\text {horizontal(orvertical)_GRA_nu.in. }}^{\prime}=\sum \varphi(Z) \cdot \cos Z_{i} \cdot \sin Z d \alpha d Z \\
& I^{\prime} \text { horizontal(orvvertical)_IND_nu.in. }=\sum f(\chi) \cdot \cos Z_{i} \cdot \sin Z d \alpha d Z \\
& I^{\prime} \text { horizontal(orvvertical)_CIE_mu.in. }=\sum f(\chi) \varphi(Z) \cdot \cos Z_{i} \cdot \sin Z d \alpha d Z
\end{aligned}
$$

注 5$)$ 本研究では, Indicatrix 近似関数の係数については, $Z_{s}, \alpha^{\prime}$ ともに $10^{\circ}$ 間隔で求めている. $Z_{s}, \alpha^{\prime}$ がこの $10^{\circ}$ 間隔の值と一致している場合の精 度は良いが, これを外れると精度の低下が起こる可能性が考えられる。 そこで, $10^{\circ}$ 間隔の值の中間となる太陽方位が $45^{\circ}$ の場合の相対日射量 の相対誤差を求め確認した. 相対誤差の最大値は $2.2 \%$ であり, 大きな精 度の低下はみられなかった ${ }^{211}$ 。

注 6) 本研究では, 壁面日射量・熱負荷計算に, 京都大学吉田研究室で開発 した熱負荷シミュレーションソフトACSES を利用している. ACSESは, MathWorks 社の数值解析ソフトウェアMATLAB ${ }^{22)}$ のプログラミング言語 により記述されている.このプログラミング言語はインタプリタ言語で あり、コンパイル言語に比べ計算時間を要すことが考えられる。このた め, ACSES より壁面日射量計算のサブルーチンを取り出し, コンパイル 


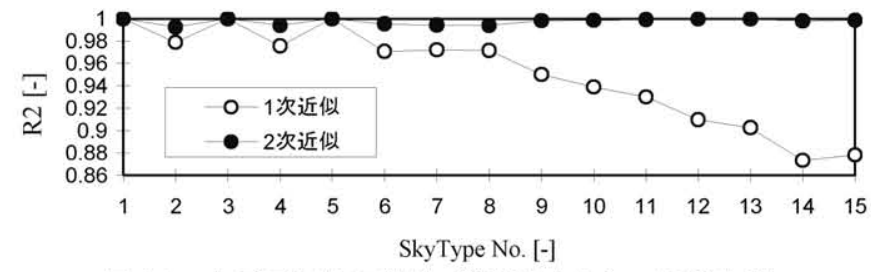

図 14 水平面相対日射量（遮蔽物なし）の近似次数

表 7 水平面相対日射量（遮蔽物なし）の近似式係数

\begin{tabular}{|c|c|c|c|c|c|c|c|c|}
\hline & \multicolumn{8}{|c|}{ SkyType No. } \\
\hline & 1 & 2 & 3 & 4 & 5 & 6 & 7 & 8 \\
\hline j1 & - & -0.0002 & - & -0.0001 & - & -0.0001 & -0.0002 & -0.0003 \\
\hline$j 2$ & - & -0.0290 & - & -0.0130 & - & -0.0076 & -0.0143 & -0.0231 \\
\hline j3 & 7.3145 & 12.3740 & 4.1387 & 6.7998 & 3.1413 & 5.0288 & 6.5172 & 8.5869 \\
\hline
\end{tabular}

\begin{tabular}{|c|c|c|c|c|c|c|c|}
\hline \multicolumn{8}{|c|}{ SkyType No. } \\
\hline 9 & 10 & 11 & 12 & 13 & 14 & 15 & \\
\hline-0.0001 & -0.0001 & -0.0002 & -0.0002 & -0.0002 & -0.0001 & -0.0002 & $j 1$ \\
\hline-0.0015 & -0.0013 & -0.0006 & 0.0015 & 0.0031 & 0.0030 & 0.0045 & $j 2$ \\
\hline 2.7839 & 3.4639 & 4.4088 & 3.0029 & 3.7864 & 2.0152 & 2.7422 & j3 \\
\hline
\end{tabular}

言語である C 言語で記述し直し，これを用いて計算時間を比較した．計 算に使用したPCのスペックは, CPU:Intel Core2Duo E8500@3.16GHz, RAM:1.99GB である.

注 7) 単純なモデル（正対する遮蔽物が 1 つある, 1 壁面で外気と接する室） を設定し, この場合の熱負荷計算全計算時間に占める, 本手法による壁 面日射量計算時間の割合を求めたところ $12 \%$ であった，壁面日射量計算 に数值積分 (分割幅は高度方向, 方位方向ともに $1^{\circ}$ ) を用いた場合には, この割合は $33.2 \%$ となる ${ }^{211}$. 熱負荷計算全計算の $1 / 3$ が壁面日射量の計 算に占められている.これから壁面日射量計算の計算時間を短縮するこ とは, 熱負荷計算全計算時間の短縮につながることがわかる.

\section{記号表}

$\varphi(Z) \quad$ : Gradation 関数 [-]

$\hat{\varphi}(Z) \quad$ : Gradation 関数の近似関数 $[-]$

$f(\chi) \quad$ : Indicatrix 関数 $[-]$

$f_{\alpha^{\prime}}^{a} \quad:$ Indicatrix 関数の天頂側関数 [-]

$f_{\alpha^{\prime}}^{g} \quad:$ Indicatrix 関数の地平線側関数 [-]

$\widehat{f}_{\alpha^{\prime}}^{a} \quad:$ Indicatrix 関数の天頂側近似関数 [-]

$\hat{f}_{\alpha^{\prime}}^{g} \quad$ : Indicatrix 関数の地平線側近似関数 [-]

$L_{a} \quad$ : 任意の天空要素の輝度 $\left[\mathrm{cd} / \mathrm{m}^{2}\right]$

$L_{z} \quad:$ 天頂輝度 $\left[\mathrm{cd} / \mathrm{m}^{2}\right]$

$\chi \quad$ : 太陽と天球上任意点の角距離 [rad]

$Z \quad$ : 天球上任意点の天頂角 [ $\mathrm{rad}]$

$Z_{s} \quad$ : 天頂からの太陽高度 (天頂角) [rad]

$Z_{i} \quad$ : 検討面への入射角 [ $\left.\mathrm{rad}\right]$

$Z^{\prime} \quad$ : 太陽高度を原点とした高度 [ $\left.\mathrm{rad}\right]$

$\alpha \quad$ : 天球上任意点の方位角 [rad]

$\alpha_{s} \quad$ : 太陽方位角 [rad]

$\alpha_{r} \quad$ : 傾斜面の方位角 [rad]

$\alpha^{\prime} \quad$ : 太陽方位を原点とした方位角 [ $\left.\mathrm{rad}\right]$

$\Delta \alpha^{\prime} \quad$ : Indicatrix 近似関数の分割幅 [rad]

$n \quad$ : Indicatrix 近似関数の分割個数 [-]

$\alpha \quad$ : 壁面方位 [rad]

$j_{1}, j_{2}, j_{3} \quad:$ 遮蔽のない場合の CIE 標準一般天空の水平面天空日射量 近似式の係数 [-]

$a, b, c, d, e \quad:$ CIE 標準一般天空のパラメータ [-]

$g_{1}, g_{2}, g_{3} \quad:$ Gradation 関数の近似関数の係数 [-]

$f_{a 1}, f_{a, 2}, f_{a, 3} \quad$ : Indicatrix 関数の天頂側近似関数の倸数 [-]

$f_{g 1}, f_{g, 2}, f_{g, 3} \quad:$ Indicatrix 関数の地平線側近似関数の係数 [-]

$a_{1}, a_{2} \quad$ : 遮蔽のある場合の方位方向の積分区間の下端・上端 [ $\left.\mathrm{rad}\right]$

$z_{1}, z_{2}$ : 遮蔽のある場合の高度方向の積分区閒の下端・上端 [ $\left.\mathrm{rad}\right]$

$I \quad$ : 天空日射量 $\left[\mathrm{W} / \mathrm{m}^{2}\right]$

$I^{\prime} \quad:$ 相対天空日射量 [-]

$E_{\text {ed }}:$ 水平面天空日射量測定値 $\left[\mathrm{W} / \mathrm{m}^{2}\right]$

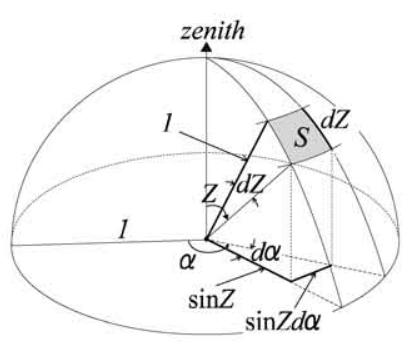

天球 (単位球) 上の微小面要素の面積 $S$ は, 以下で与えられる。

$S=\sin Z d \alpha \cdot d Z$

この微小面要素の放射輝度を $R$ とすれば,

この微小面要素より, 面 (入射角 $Z_{i}$ ) の受

ける放射照度 $i$ は以下となる.

図 15 天球上の微小面要素

\section{添え字}

$s h$ : 傾斜面, horizontal : 水平面, vertical : 鉛直面, nonshaded : 遮蔽無し, $C I E: \mathrm{CIE}$ 標準一般天空, $G R A:$ Gradation 関数, IND : Indicatrix 関数, nu.in. : 数值積分

\section{参考文献}

1) Hay, J.E., S.: Study of Short-wave Radiation on Nonhorizontal Surfaces, Canadian Climatic Center Report, No.79-12, Atmosphereic Environments Service, Toronto Canada, 1979

2) Reindl, D.T.,Beckman, W.A. and Duffie, J.A., S.: Evaluation of Hourly Tilted Surface Radiation Models, Solar Energy, Vol.45, No.1,pp.9-17, 1990

3) Perez, R.,Seals,R.,Ineichen, Stewart, R., and Menicucci, D.: A New Simplified Version of the Perez Diffuse Irradiance Model for Tilted Surfaces, Solar Energy, Vol.39, No.3, pp.221-231, 1987

4) Perez, R.,Ineichen, P.,Seals,R.,Michalsky,j., and Stewart, R.: Modeling Day Light Availability and Irradiance Components from Dirct and Global Irradiancen, Solar Energy,44(5), pp.271-289, 1990

5) Igawa,N., Koga,Y., Matsuzawa,T. and Nakamura, H. :Model of Sky Radiance Distribution and Sky Luminance Distribution ,Solar Energy,77,pp.137-157,2004

6) Brunger,A.P., Hooper,F.C.A.: Anisoropic sky Radiance Model Based on Narrow Field of View Measurements of Shortwave Radiance, Solar Energy,51(1), pp.53-64, 1993

7) Kittler, R.: Luminance Distribution Characteristics of Homogeneous Skies, A Measurement and Prediction Strategy, Lightning Res. \& Tech., Vol.17, No.4, pp.183-188, 1985

8) Perez, R., Seals,R. and Michalsky,j. :All-Weather Model for Sky Luminance Distribution - Preliminary Configuration and Validation,

Solar Energy, 50(3), pp.235-245,1993

9) http://apps1.eere.energy.gov/buildings/energyplus/energyplus_about.cfm, 2012.2.11 参照

10) 細淵勇人, 吉田治典, 上谷芳昭 : 天空放射輝度分布への CIE 標準一般天 空の流用と天空タイプの集約 日本建築学会環境系論文集，第 583 号， pp. 29-36,2004.9

11) 細淵勇人, 吉田治典, 上谷芳昭 : 日射量を用いた CIE 標準一般天空の天 空タイプ推定手法に関する研究, 日本建築学会環境系論文集, 第 609 号, pp.31-38, 2006.11

12) 細淵勇人, 吉田治典 : 天空放射輝度分布が空調熱負荷に与える影響に関 する研究 - 京都実測データによる天空放射輝度分布を考慮した熱負荷 計算-, 日本建築学会環境系論文集, No.631, pp.1101-1108, 2008.9

13) 細淵勇人, 吉田治典: 天空放射輝度分布を考慮した壁面日射量計算法の 開発, 日本建築学会大会学術講演梗概集 D-2, pp. 7-8, 2009.8

14) 細淵勇人, 吉田治典: 天空放射輝度分布を考慮した壁面日射量計算法の 開発, 日本建築学会近畿支部研究報告集 環境系, 2009.6

15) 細淵勇人, 吉田治典: 天空放射輝度分布、及び遮蔽物を考慮した 壁面日射量・熱負荷計算, 日本建築学会大会学術講演梗概集 D-2, pp. 509-510, 2010.9

16) Kittler, R.: Standardization of outdoor conditions for the calculation of daylight factor with clear skies, Proc. the CIE International Conference on Sunlight in Buildings, Bouwcentrum Internationl, Rotterdam, pp.273-285, 1967

17) Nakamura, H., Oki, M., Hayashi, Y.: A Study on the Estimation of the Relative Frequency of Occurrences of the Clear Sky, the Intermediate Sky and the Overcast Sky in Japan, J.Light \& Vis.Env., Vol.9, No.2 , pp.76-85, 1985

18) Littlefair, P.J.: The Luminance Distribution of an Average Sky, Lightning Res. \& Tech., Vol.13, No.4, pp.92-98, 1981

19) Perraudeau, M.: Luminance Models, National Lighting Conference 1988, Cambridge, pp.291-292, 1988

20) Harrison, A.W.: Directional sky luminance versus cloud cover and solar position, Solar Energy,46(1), pp.13-19, 1991

21) 細淵勇人: 京都大学博士学位論文, 2009.3

22) http://www.mathworks.co.jp/products/matlab/, 2012.2.11 参照 